
反強磁性界面におけるねじれた磁化の観察

\author{
雨宮 健太 ${ }^{1}$, 鈴木 真粧子 ${ }^{1,2}$ \\ (高エネルギー加速器研究機構 ${ }^{1}$, 群馬大学 ${ }^{2}$ )
}

\title{
Observation of Twisted Magnetization at Ferromagnet/Antiferromagnet Interface by Means of Polarized Neutron Reflectivity and Soft X-ray Depth-resolved X-ray Magnetic Circular Dichroism
}

Kenta Amemiya ${ }^{1}$ and Masako Suzuki-Sakamaki ${ }^{1,2}$

High Energy Accelerator Research Organization ${ }^{1}$ and Gunma University ${ }^{2}$

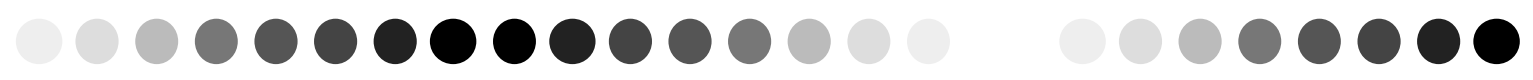

\begin{abstract}
A twisted magnetic structure in a Ni film attached to an antiferromagnetic FeMn layer is suggested by a complimentary use of the polarized neutron reflectivity (PNR) and the depth-resolved X-ray magnetic circular dichroism (XMCD) techniques. The depth-resolved XMCD shows that the perpendicular magnetization component in the $\mathrm{Ni}$ film decreases around the interface to FeMn, while the PNR data indicates that an in-plane magnetization component is induced in $\mathrm{Ni}$ around the interface to FeMn by weak in-plane magnetic fields. These results are reasonably interpreted by assuming that the magnetic moment in the Ni layer is twisted from the perpendicular to the in-plane directions towards the interface to FeMn.

Keywords: Depth-resolved X-ray magnetic circular dichroism, Polarized neutron reflectivity, Ferromagnetic-antiferromagnetic interaction, Magnetic anisotropy
\end{abstract}

1.はじめに

磁性薄膜において，深さ方向の磁化の分布をナ ノメーターもしくはそれ以下のスケールで観察す ることは，非常に重要かつ困難である。例えば本 稿で取り上げる強磁性体と反強磁性体の界面にお いては，磁気モーメントの揃った強磁性体と，原 子単位で磁気モーメントが逆を向いている反強磁 性体がいきなり接するため，界面における強い磁 気的相互作用によって，磁気状態が原子層レベル の空間スケールで深さ方向に変化していくことが 予想される。このような界面における磁化を，深 さ方向に分解して観察できる手法として，偏極中 性子反射率（Polarized neutron reflectivity; PNR）が 知られている。これはスピン偏極した中性子を試 料表面に斜入射で照射し，その反射率を波数 $q$ の 関数として測定するものである。一方，著者らは 十数年前から，円偏光 $\mathrm{X}$ 線の吸収スペクトルから 元素ごとの磁気モーメントの情報が得られるX $\mathrm{X}$ 線 磁気円二色性（X-ray magnetic circular dichroism; XMCD）において，X 線吸収に伴って放出される 電子を角度分解して検出することで深さ方向の情 報を得る, 深さ分解XMCDを開発してきた 1,2$]$.

本稿では，膜厚の増加とともに特異な磁気異方 性変化を示すことが知られている $\mathrm{Ni}$ 薄膜と, 典型 的な反強磁性金属である FeMn 合金の薄膜との界
面における磁化の深さ方向の分布を，偏極中性子 反射率と軟 X 線深さ分解 XMCD を相補的に用い て観察した研究を紹介する $[3,4]$.

\section{2. $\mathrm{FeMn} / \mathrm{Ni} / \mathrm{Cu}(001)$ の磁気異方性}

$\mathrm{Cu}(001)$ 単結晶表面に成長させた $\mathrm{Ni}$ 薄膜は，膜 厚が薄い時には面内方向に磁化容易軸を持つが，

7-11 ML (monolayer; 原子層) 程度で面直磁化へ と転移し, さらに 30-50 ML 程度で再び面内磁化 を示すことが知られている $[5,6]$.この Ni 薄膜に, 反強磁性体である FeMn を接合させると, Ni の磁 気異方性によ゙のような変化が起こるだろうか。 な お， FeMn は fcc 型の不規則合金で, $\mathrm{Ni} / \mathrm{Cu}(001)$ の 上では(001)面がそのまま成長する[7]. また, FeMn の磁気構造はいささいか複雑で，それぞれのサイ トのスピンは斜め方向を向いているが，(001)面で 見ると，原子層内の磁気モーメントのベクトル和 が層ごとに土 $\mathrm{z}$ 方向で交互に入れ替わる, 一種の層 状反強磁だと言われている[7,8].

Fig. 1 に， $\mathrm{Cu}(001)$ 単結晶表面に，場所によって 厚さの異なる（wedge 状の） Ni 薄膜を成長させ, その上に均一な厚さの FeMn を順次成長させて, 残留磁化状態において室温で測定した Ni L 吸収 端 XMCD の強度変化を示す[3]. X 線ビームを当 てる位置を変えることで, Ni の膜厚依存性を測定 
している. XMCD 強度は磁化をビームの進行方向 に射影した成分を反映するが，このデータは直入 射条件で測定したものなので，磁化の面直成分を 観察していることになる。まず FeMn が無い状態 では, 過去の報告と同様に $\mathrm{Ni}$ の膜厚 $9 \mathrm{ML}$ 程度を 境に面直磁化が現れる。これに FeMn を成長させ ると, FeMn 膜厚 $10 \mathrm{ML}$ において, 面直磁化が現 れる Ni 膜厚（転移膜厚）が $6 \mathrm{ML}$ 程度へと大幅に シフトする。すなわち，膜全体として垂直磁化を 示寸傾向が強くなる。 ところが，さらに FeMn を 15-25 ML へと成長させると, 今度は逆に面内磁化 を示寸領域が拡がっていく。

これらの磁気異方性変化のうち, FeMn 膜厚が $10 \mathrm{ML}$ 程度までの薄い領域で起こる面直磁気異方 性の増強は, $\mathrm{Ni}$ 表面の状態変化によるものと推測 される。というのは, $\mathrm{Ni}$ 薄膜が直接真空と接して いる場合には, 表面 $\mathrm{Ni}$ 層は面内磁化を強く好むた め，そこに $\mathrm{Cu}$ を成長させたり分子を吸着させた りすることで，面直磁気異方性が増強されること が知られているからである $[5,6]$. 一方, FeMn 膜 厚を $10 \mathrm{ML}$ から $25 \mathrm{ML}$ へと増加させることによっ て起こる面内磁気異方性の増強は, FeMn の膜厚 の増加に伴って Néel 温度が上昇し[8], FeMn が室 温で反強磁性を示すようになることに伴う変化で あると考えられる.なお，ここで観察された FeMn 膜厚の増加に伴う面内磁気異方性の増強は, 過去 の報告と一致している[7]. 本研究では，このよう な磁気異方性変化の起源を探るために, FeMn と $\mathrm{Ni}$ の界面における磁化の深さ方向分布の観察を 行った.

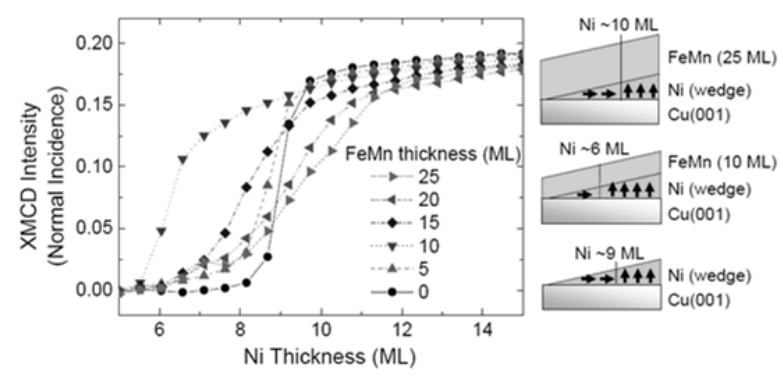

Fig. 1. Ni thickness dependence of normal-incidence Ni L-edge XMCD intensity at remanent state for different FeMn thicknesses.

\section{3. 軟 X 線深さ分解 XMCD による観察}

Fig. 2(a)に深さ分解 XMCD の測定原理を模式的 に示す. 軟 X 線領域の XMCD 測定においては, 透過 $\mathrm{X}$ 線強度の測定が極めて困難なため, 電子収 量法と呼ばれる手法が用いられることが多い。こ れは，X 線の吸収によって生じる内殼空孔が緩和 する際に放出される Auger 電子（およびそれに伴 って発生する 2 次電子) を検出し，その数が吸収 強度に比例することを利用するものである。この 時, 試料内部における X 線吸収に伴って放出され た電子は, 表面に到達するまでに減衰するため(典 型的な減衰長は数 $\mathrm{nm}$ ), 電子収量法によって測定 したデータは, 表面付近で起こった X 線吸収の情
報を多く含むことになる，さらに，表面すれ寸れ 方向に放出される電子は，表面垂直に放出される 電子に比べて, より長い距離を通らないと表面に 到達できないために，より浅いところの情報の占 める割合が大きくなる。したがって，Fig. 2(a)に示 すように，位置分解能を有する電子検出器を用い て, 様々な検出角 $\left(\theta_{\mathrm{d}}\right)$ で Auger 電子を検出すること によって, 様々な検出深度 $\left(\lambda_{\mathrm{e}}\right)$ の XMCD データを 一度に得ることができる。本研究では，Fig. 2(b) に示す, 位置分解検出器と薄膜の蒸着源を備えた 超高真空チェンバーを, Photon Factory (PF)の軟 X 線アンジュレータビームライン（BL-16A）に接続 し, 薄膜の作製と深さ分解 XMCD の測定を, 真空 を破ることなく連続で行うことができる in-situ 実 験装置を用いて実験を行った。なお，Auger 電子 を角度分解して検出するという原理から明らかな ように,この手法は磁場中では適用できないので, 作製した薄膜を真空中に設置した電磁石によって 一度磁化してから, 残留磁化状態で XMCD 測定を 行った.
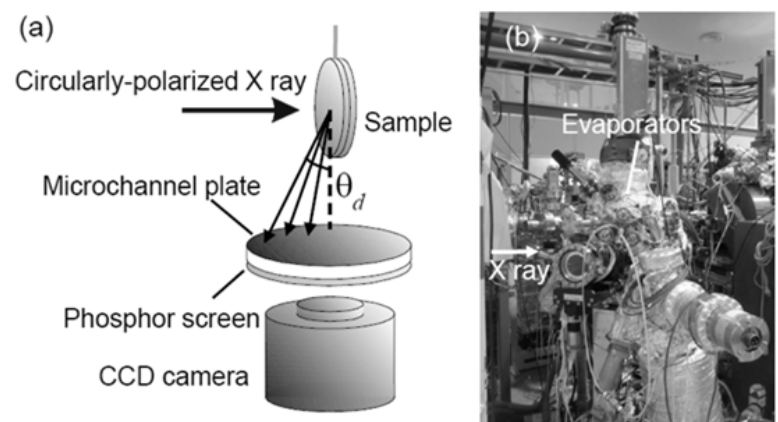

Fig. 2. (a) Schematic setup for depth-resolved XMCD technique and (b) picture of in-situ experiment chamber at PF BL-16A.

Fig. 3(a)に, 膜全体として面直磁化を示寸, 膜厚 $16 \mathrm{ML}$ の Ni 薄膜に対して測定した Ni L 吸収端 $\mathrm{XMCD}$ スペクトルの検出深度 $\left(\lambda_{\mathrm{e}}\right)$ 依存性を示す。 測定は直入射で行ったので，磁化の面直成分を観 察している。ここで, XMCD スペクトルは Ni の 量に対して規格化されているので, $\mathrm{Ni}$ 一原子あた りの磁気モーメントを反映している. FeMn 膜厚 5 ML の場合には, XMCD 強度は検出深度に依存せ ず, Ni は深さ方向に一様に磁化されていることが わかる.ところが FeMn 膜厚が増加するにつれて, XMCD 強度が減少するとともに, 表面敏感なデー 夕ほど，その減少が顕著になってくる。これは, 主に FeMn との界面付近において, Ni の磁化の面 直成分が減少していることを強く示唆している.

Fig. 3(b)に，様々な検出深度の XMCD スペクトル それぞれに対して，XMCD の総和則 $[9,10]$ を適用 して見積もった, 有効スピン磁気モーメント $\left(m_{\mathrm{s}}{ }^{\mathrm{eff}}\right)$ を示す. 深さ分解 XMCD で得られるのは, 特定の 深さからのシグナルではなく, 深さ $z$ に応じた減 衰因子 $\exp \left(-\mathrm{z} / \lambda_{\mathrm{e}}\right)$ のかかった，すべての深さから のシグナルの加重平均である $[1,2]$. したがって, 
Fig. 3(b)がそのまま磁気モーメントの深さ分布を 表すわけではないが，FeMn との界面付近におい てNi の磁化の面直成分が減少していることが, ほ ぼ直接的に示されたといっていいだろう。このよ うな変化は, FeMn がかなり厚い領域で生じてい るため, 界面での軌道混成などによって Ni の状態 そのものに影響を及ぼしているというよりは， FeMn の膜厚が増加して反強磁性的な性質を示す ことに伴う，強磁性／反強磁性の磁気的相互作用 によって, Ni の磁化に変化が生じていると考える のが妥当であろう。
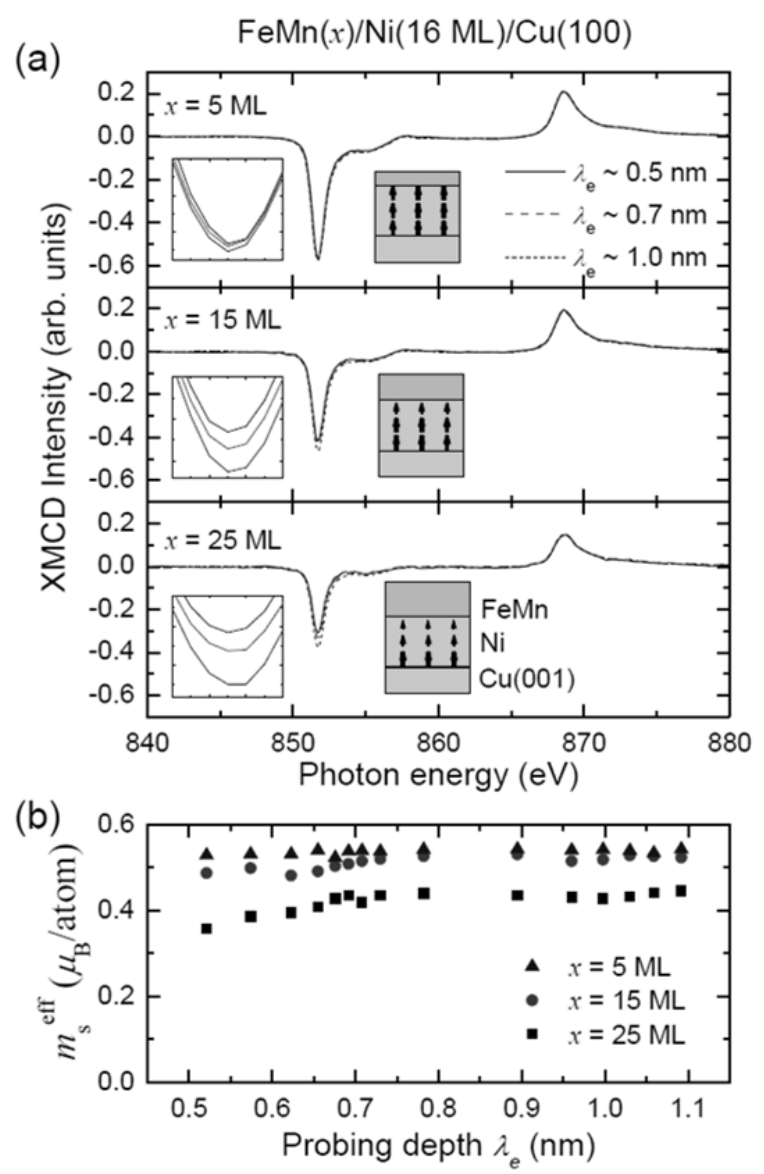

Fig. 3. (a) Probing depth $\left(\lambda_{\mathrm{e}}\right)$ dependence of normal-incidence Ni L-edge XMCD spectrum for FeMn $(x$ ML) / Ni (16 ML) / Cu(001) and (b) effective spin magnetic moment $\left(m_{\mathrm{s}}{ }^{\text {eff }}\right)$ estimated from each XMCD spectrum as a function of $\lambda_{\mathrm{e}}$.

次に，膜全体として面内磁化を示す，膜厚 6.5 MLの Ni 薄膜に対して同様に測定した Ni L 吸収 端深さ分解 XMCD の結果を Fig.4 に示す. この場 合は，磁化の面内成分を検出するために，斜入射 条件で測定を行った（直入射から 60 度, 試料を回 転). なお, 検出深度は入射角ではなく Auger 電子 の検出角で決まるため, 斜入射条件でも全く同様 に深さ分解 XMCD 測定を行うことができる． Ni 膜厚 $6.5 \mathrm{ML}$ の場合, 室温では $\mathrm{Ni}$ の磁化があまり 大きくないことと，完全に面内方向に X 線を入射 しているわけではないことから，XMCD 強度その ものは若干小さいが, 面直磁化の場合とは異なり,
FeMn 膜厚が $15 \mathrm{ML}$ でも XMCD 強度は検出深度に ほとんど依存していない。すなわち, Ni の磁化の 面内成分は, FeMn との界面でも内部層と同程度 に保たれていることが明らかになった。

以上のように, 軟 X 線深さ分解 XMCD の結果 から，FeMn が反強磁性的な性質を示すようにな ると, Ni の磁化が面直方向を向いているときには FeMn との界面付近で（面直方向の）磁化が減少 し, 面内方向を向いているときには, 界面でも（面 内方向の）磁化が減少しない，ということが見え てきた。これに, 先に述べた FeMnによる Ni の面 内磁気異方性の増強を合わせて考えると, 一つの 仮説が浮かびあがってくる。すなおち, FeMn と の界面付近で, Ni の磁化が面内方向を向きやすく なっているという描像である。もしこの仮説が正 しければ, Niが十分に厚くて, 全体としては面直 方向に磁化が向いている場合には, FeMn との界 面付近で磁化が面内方向に傾くことにより, 磁化 の面直成分が減少すると説明できるし, Ni が薄く て膜全体として面内磁化を示年合には，FeMn との界面はそのまま面内磁化を保つと理解できる. この仮説を検証するには, Ni が全体としては面直 磁化を示す状態で, 界面に生じると予測される面 内磁化成分を観察すればよいが，一言に面内と言 っても, $\mathrm{Cu}(001)$ 表面は 4 回対称を有するため, 面 内での磁化方向を揃えるために，ある程度の外部 磁場を印加する必要がある。ところが, 上述の通 り深さ分解 XMCD は, 磁場中では測定できない. そこで, 磁場中で深さ方向の磁化分布を知ることが できる，偏極中性子反射率を利用することとした。

(a)
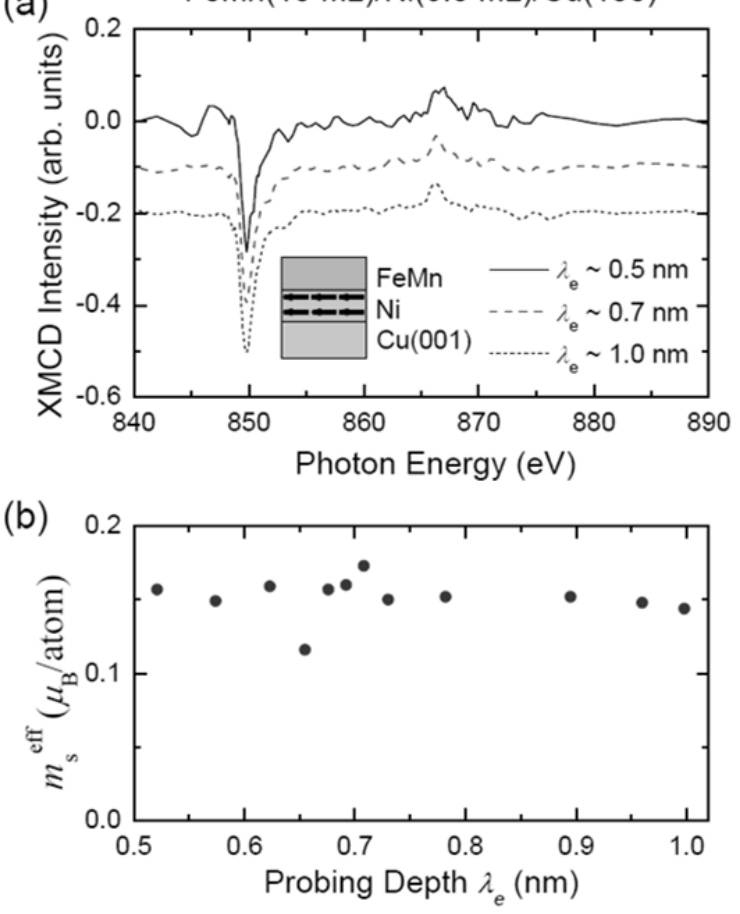

Fig. 4. (a) Probing depth $\left(\lambda_{\mathrm{e}}\right)$ dependence of grazing-incidence Ni L-edge XMCD spectrum for FeMn (15 ML) / Ni (6.5 ML) / Cu(001) and (b) effective spin magnetic moment $\left(m_{\mathrm{s}}\right.$ eff $)$ estimated from each XMCD spectrum as a function of $\lambda_{\mathrm{e}}$. 


\section{PNR による観察}

前節までに紹介した実験は, すべて in situ 測定， すなわち試料作製から測定までを同じ真空チェン バー内で連続して行ったものである. しかしなが ら, PNR の測定を行う J-PARC MLF の BL17 （SHARAKU）には，そのような実験装置はない ため，作製した薄膜試料に十分に厚い $\mathrm{Cu}$ を蒸着 し, 大気中に取り出しても FeMn や Ni に影響がな いようにして持ち込んだ. Fig. 5 に試料をマウン トしたホルダーと，それを電磁石を備えた反射率 計に取り付けた際の写真を示す. $\mathrm{Cu}(001)$ 基板は 甲10 mm の円板で, その全面に Ni (11 ML), FeMn (21 ML)および $\mathrm{Cu}$ (74 ML)を順次成長させてある. Fig. 1 からわかるように，これらの膜厚の組み合 わせは, Ni 薄膜全体としてはほぼ面直磁化を示寸 が，面内磁化成分もわずかに含まれているという 微妙な領域であり，面内方向に磁場をかけること で容易に磁化の向きを制御できると期待される.

なお，MLF BL17では，中性子の偏極，印加磁場 ともに鉛直方向を向いており, 試料は縦置き配置

（法線が水平方向）になっている。つまり，鉛直 方向（試料表面から見ると面内方向）の磁化成分 を観察することになる。したがって，ほぼ面直磁 化を示す今回の試料の場合, 磁場を印加しないと 偏極シグナルは観測されず，鉛直方向に磁場を印 加することで，少しずつシグナルが増加すること が期待される.

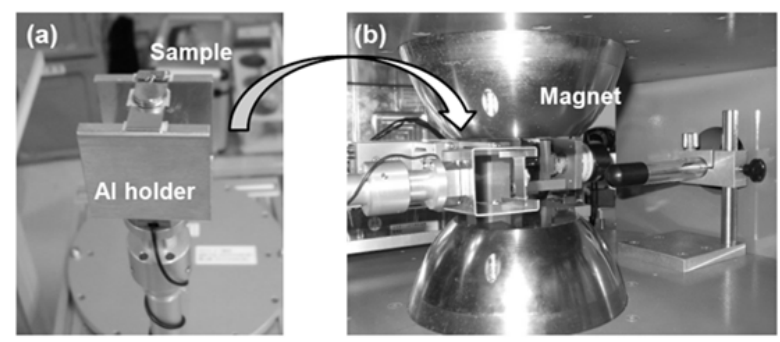

Fig. 5. (a) Cu (74 ML) / FeMn (21 ML) / Ni (11 ML) / $\mathrm{Cu}(001)$ sample mounted on Al holder and (b) PNR apparatus at MLF BL17 (SHARAKU).

Fig. 6 に, $1 \mathrm{kOe}$ の磁場中で測定した PNR デー 夕を示寸 [3]. もともと面直磁化を示寸試料なので, PNR シグナル（偏極による反射率の違い）はかな り小さいが, 磁場によって誘起された面内磁化成 分を確かに観測できている. 残念ながら, 得られ た反射率曲線から直感的に, 磁化がごこにあるの か ( FeMn との界面付近なのか $\mathrm{Ni}$ 薄膜の内部なの か）を区別することはできないが，反射率曲線を 適切なパラメータを用いて解析することで, 磁化 の深さ方向分布を求めることができる.ここでは, 磁化は $\mathrm{Ni}$ のみが持つものとし（FeMn は反強磁性 なので大きくは間違っていないであろう), Ni 薄 膜を FeMn との界面と残りの内部層の二つの領域 に分割して，それぞれの領域の厚さと（面内方向 の）磁気モーメントをパラメータとした。 なお, 他にも $\mathrm{Cu}$ 層と $\mathrm{FeMn}$ 層の膜厚と散乱長密度, お
よび，それぞれの界面の粗さもパラメータにして いる.フィッティングによって得られた結果は, Fig. 6 に示寸通り, FeMn との界面層(1 ML)の磁気 モーメントが $0.32 \mu_{\mathrm{B}} /$ atom, 内部層(10 ML)のそれ が $0.20 \mu_{\mathrm{B}} /$ atom となり, FeMn との界面において $\mathrm{Ni}$ の磁化の面内成分が大きいことがわかる.これ は上述の仮説，すなわち FeMn との界面付近で $\mathrm{Ni}$ の磁化が面内方向を向きやすくなっており, $\mathrm{Ni}$ 全 体としては面直磁化を示寸場合にも, 界面付近で は磁化が面内方向に傾いているという描像を強く サポートするものである. なお, 解析では単純化 のために Ni を2つの領域に分割したが, 実際には $\mathrm{Ni}$ の内部から FeMn との界面に向かって徐々に磁 化が傾いていく,「ねじれた磁化」という描像がも っともらしいと思われる。

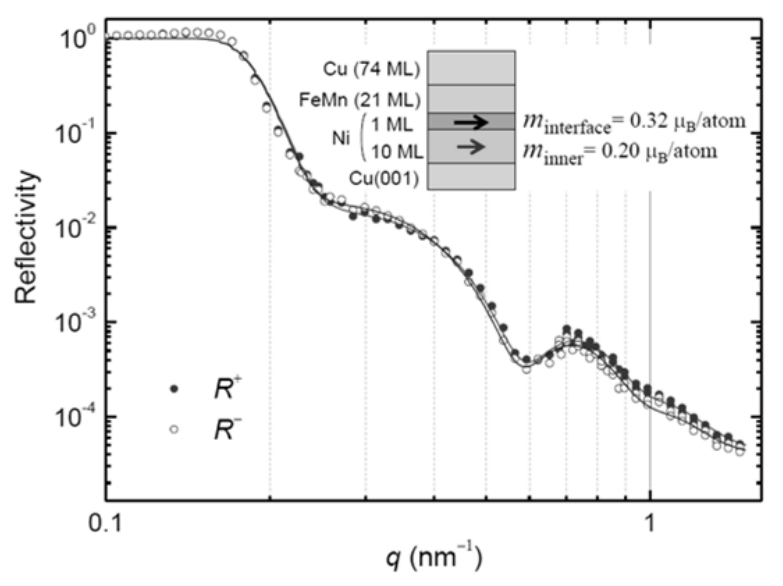

Fig. 6. PNR curves (points), $R^{+}$and $R^{-}$, for $\mathrm{Cu}(74$ ML) / FeMn (21 ML) / Ni (11 ML) / Cu(001) measured at $1 \mathrm{kOe}$ magnetic field, together with simulated curves (lines).

最後に，これまでの測定から示唆された「ねじ れた磁化」が，外部磁場によってどのように変化 するかを調べるために, PNR の磁場依存性を測定

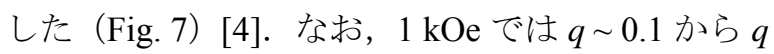
$\sim 1.5 \mathrm{~nm}^{-1}$ の範囲で測定を行ったが, 特に高い $q$ 領 域の測定は非常に時間がかかるので, 磁場依存性 の測定では $q$ の範囲を限定した. また, 偏極シグ ナルを見や寸く寸るために，異なる偏極に対する 反射率の差 $(\Delta R)$ を反射率の平均值 $\left(R^{\mathrm{av}}\right)$ で割った值 を Fig. 7(b)に示した.

この試料は, 残留磁化状態でほぼ面直磁化を示 寸ため, 外部磁場がない場合には有意な PNR シグ ナルは見られない，そこから磁場を大きくするに つれてシグナルも増加し, $10 \mathrm{kOe}$ でほぼ飽和に達 寸る. これら一連の反射率曲線に対して, 先ほど と同様に Ni を二つの領域に分割したモデルを用 いてフィッティングを行って得られた, Ni の界面 層と内部層の磁気モーメントを Fig. 8 に示寸.

FeMn との界面層の磁化 $\left(m_{\text {interface }}\right)$ は, 比較的小さい 磁場で急激に立ち上がり, $2-5 \mathrm{kOe}$ 程度でほぼ飽和 する. 一方内部の $\mathrm{Ni}$ 層の磁化は $\left(m_{\text {inner }}\right)$, 磁場の増 加につれてゆっくりと増加していく.ここで観察 
しているのは，いずれも磁化の面内成分であるこ とに注意ししながら, Ni 薄膜内の磁気構造を推測 すると，Fig. 8 に示すように，まず界面付近の磁 化が面内方向に傾きはじめ，磁場の増加につれて 内部の方の磁化も面内方向に傾いていくという状 況が想像できる。このように，軟 X 線深さ分解 XMCD と偏極中性子反射率の相補的な利用によ って，反強磁性 FeMn との界面において，Ni の磁 化が面直から面内方向へと㸚じれていくことを示 唆する結果を得ることができた。
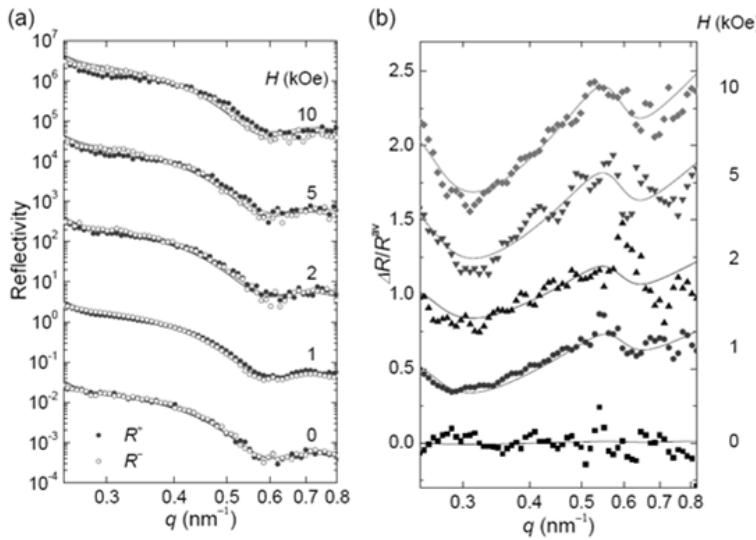

Fig. 7. (a) PNR curves, $R^{+}$and $R^{-}$, for $\mathrm{Cu}(74 \mathrm{ML})$ / FeMn (21 ML) / Ni (11 ML) / Cu(001) measured at different magnetic fields, $H$, and (b) difference, $\Delta R=R^{+}-R^{-}$, divided by average, $R^{\mathrm{av}}=\left(R^{+}+\right.$ $\left.R^{-}\right) / 2$, of them, together with simulated curves. The data for different $H$ are vertically shifted.

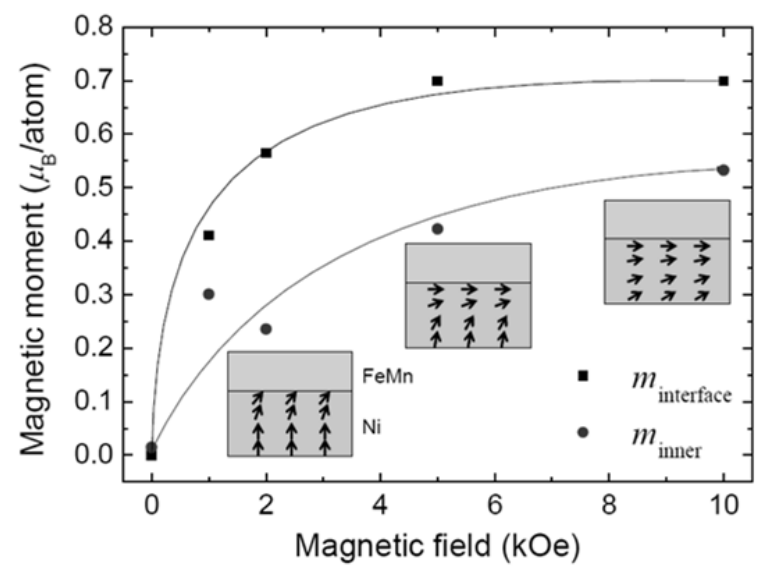

Fig. 8. In-plane component of the magnetic moment in the interface and inner region of the $\mathrm{Ni}$ film estimated by fitting the PNR curves as a function of applied magnetic field, $H$. The lines are guides to eye. The expected magnetic structure is schematically illustrated.

\section{FeMn による磁気異方性変化の起源}

以上の結果は，FeMn との界面において Ni の面 内磁気異方性が増強されることに起因すると考え られるので，ここでは，そのような磁気異方性変 化の起源について述べる。上述の通り，この変化 は FeMn が十分厚くなってから起こるので，界面 における軌道混成などによる Ni の電子状態の変 化というよりは，FeMn の反強磁性的な磁気構造
が影響していると考えるのが自然であろう.実際， FeMn による Ni の面内磁気異方性の増強は, 過去 にも報告されており，その起源は以下のように説 明されている[7]. 上述の通り，FeMn は(001)面内 の磁気モーメントのベクトル和が，上向きと下向 きで層ごとに交互に入れ替わる，一種の層状反強 磁性と考えられる。したがって, FeMn/Ni 界面が 完全に平坦であれば， Ni と接する FeMn 層は全て 同じ向きの磁化を持つが, 実際の Ni 薄膜には必ず 原子層ステップが存在するため, その上に FeMn を成長させると，ステップを一つ上がるごとに， $\mathrm{Ni}$ と接する FeMn 層の磁化が上向きと下向きの間 で交互に変化することになる。このような状態で $\mathrm{Ni}$ が面直磁化を持つと，ある部分では界面の FeMn 層の磁化と並行だが，一つステップを上が ると反平行という，非常に不自然な状態を生じて しまう。一方, Ni が面内磁化であれば, 界面 FeMn 層と $\mathrm{Ni}$ の磁化は, ステップに関わらず常に直交す ることになり，少なくともフラストレーションは 解消される。これが，FeMn が反強磁性的な性質 を示すことによって Ni の面内磁気異方性が増強 される起源と考えられている。

\section{PNR と深さ分解 XMCD の相補性}

最後に，この特集の主題である，プローブの相 補性について述べたい，XMCD は，それ自体では 深さ方向の分析はできないが，電子の出射角を分 解することで原子層レベルの分解能を持つ深さ分 解XMCD を実現することができた.一方 PNRは, もともと深さ分解分析のための手法といっても過 言ではなく，原理的に原子層レベルの深さ分解能 を実現できる。このように，いずれの手法も深さ 分解した磁気解析を目的としているが，筆者の感 じる最も大きな違いは, 深さ分解 XMCD の方が直 感的であるという点である。もともと XMCD 自体 が直感的にわかりやすい手法で，例えば Fig. 3 の ようなデータを見れば, 他でもない Ni が磁化を持 っていることが一目瞭然である.さらに深さ分解 XMCD でも, 検出深度が浅いデータの方が XMCD 強度が小さければ，表面（ここでは FeMn との界 面）付近の磁化が小さいということが容易に結論 できる.これに対して PNR では，Fig. 7 のような データを見ても, シグナルが Ni に由来するかどう かもすぐにはわからないし，ましてや界面層が内 部層よりも大きな面内磁化を持っていることは, 本格的な解析をしない限りわからない（もつと慣 れてくれば「神の眼」を持つこともできるのかも しれないが).ただし, 深さ分解 XMCD の結果を 直感的に解釈できるのは，基本的には表面に近い 側だけである。例えば今回のような試料で， $\mathrm{Cu}$ との界面の磁化がどうなっているかを，データか ら直接予測するのはほとんど不可能である。いず れにせよ,「直感的」という表現は必ずしも科学的 ではないが，実際に得られた結果を自信を持って 世に送り出すために，極めて重要なことだと感じ ている. 
もう少し「科学的」に，これらの手法の長所と 短所を考察したい。一つ忘れてはいけないのは, PNR は面内磁化を観察する手法であり，面直磁化 の解析は出来ないという点であるが，ここでは面 内磁化を想定して考察を続ける. 深さ分解 XMCD は，表面付近において元素選択的に磁化の深さ分 布を原子層レベルの分解能で観察できる.ただし, 表面から遠くなるほど解析は困難になる。また， 今回の試料のように表面側が別の元素からなる膜 で覆われている場合にも，元素選択性のおかげで 解析は可能であるが, 電子は被覆層を通る間にも 減衰するので, $\mathrm{S} / \mathrm{N}$ 比は文字通り指数関数的に悪 化するし，被覆層から放出される（吸収スペクト ルそのものには寄与しない）電子によって $\mathrm{S} / \mathrm{B}$ 比 も大幅に悪化する。例えば，最表面から放出され る電子の量を 1 とすると, 深さ $1 \mathrm{~nm}$ からの電子 は, 検出深度 $\lambda_{\mathrm{e}}=0.5 \mathrm{~nm}$ の場合 $\exp (-1 / 0.5)=0.135$, $\lambda_{\mathrm{e}}=1 \mathrm{~nm}$ では $\exp (-1 / 1)=0.368$ となり, この違い から表面層のシグナルを分離できるのだが，仮に $2 \mathrm{~nm}$ の被覆層があると，もともと 1 であった最表 面（この場合は界面）からの電子の量は， $\lambda_{\mathrm{e}}=0.5$, $1 \mathrm{~nm}$ に対してそれぞれ $0.018,0.135$ にまで減少し,

（界面から測って）深さ $1 \mathrm{~nm}$ からの電子も同様 に，0.0024，0.050まで減少する．もちろん，表面

（界面）からの電子と深さ $1 \mathrm{~nm}$ からの電子の量 の比は，被覆層の有無によらず一定なので解析の 原理は変わらないが，わずか $2 \mathrm{~nm}$ の被覆層によ って大幅にシグナル強度が減少することがよくわ かる。ちなみに，それならば $\lambda$ 在大きくすればい いと思うかもしれないが, そうすると表面(界面) からの電子と深さ $1 \mathrm{~nm}$ からの電子の量に差がつ かず，深さ分解解析ができなくなってしまう。こ のように, 深さ分解 XMCD は表面付近でこそ威力 を発揮する手法である。一方で PNR では，この程 度の被覆層によってシグナル強度が減少するよう なことはない。また，表面側の界面と基板側の界 面は，どちらも反射率曲線に寄与するので，いず れの界面も解析できる。つまり PNR は，「埋もれ た界面」の解析において，特に威力を発揮するこ とになる。

もう一つの大きな違いは，外場の影響である. 電子を角度分解する深さ分解 XMCD は, 磁場や電 場のような外場中で測定することはできない。一 方で中性子はそういった外場の影響を受けないた め, PNR は磁場中でも電場中でも全く問題なく測 定できる。これが今回，PNR との相補的な実験を 行った最大の理由である。ただ，筆者らも深さ分 解 XMCD の最大の弱点をいつまでも放置するつ もりはなく, 最近, 電子のかわりに蛍光 X 線を検 出することで, 外場中の深さ分解 XMCD 測定を実

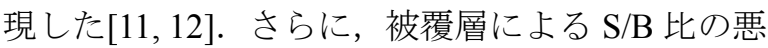
化を防ぐために，蛍光 $\mathrm{X}$ 線を分光する，蛍光選別 深さ分解 XMCD の開発も行っている[13]. とは言 え,「埋もれた界面」の分析における PNRの優位 性はゆるぎないと思われるので，今後もそれぞれ の手法を磨き合い，相補利用による界面研究を続 けていきたいと考えている。

\section{謝辞}

PNR の測定および解析においては，武田全康氏 （JAEA）と水沢まり氏（CROSS）に多大なご協 力をいただいた。 この場を借りて心から感謝の意 を表したい. 深さ分解 XMCD および偏極中性子反 射率の測定はそれぞれ，PF Program Advisory Committee（No. 2010S2-001）および MLF Program Advisory Committee（No. 2012B140）による課題採 択のもとで行った。 また，本研究は文部科学省の 量子ビーム基盤技術開発プログラム（2008-2012 年）の支援を受けて行った.

\section{参考文献}

[1] K. Amemiya et al., Appl. Phys. Lett. 84, 936 (2004).

[2] K. Amemiya, Phys. Chem. Chem. Phys. 14, 10477 (2012).

[3] K. Amemiya et al., Phys. Rev. B 89, 054404 (2014).

[4] K. Amemiya et al., JPS Conf. Proc. 8, 034004 (2015).

[5] W. L. O’Brien et al., Phys. Rev. B 54, 9297 (1996).

[6] R. Vollmer, et al., Phys. Rev B 60, 6277 (1999).

[7] J. Wu et al., Phys. Rev B 79, 212411 (2009).

[8] D. Schmitz et al., Phys. Rev. B 81, 224422 (2010).

[9] B. T. Thole et al., Phys. Rev. Lett. 68, 1943 (1992).

[10] P. Carra et al., Phys. Rev. Lett. 70, 694 (1993).

[11] M. Sakamaki and K. Amemiya, Rev. Sci. Intrum. 88, 083901 (2017).

[12] M. Sakamaki and K. Amemiya, Phys. Chem. Chem. Phys. 20, 20004 (2018).

[13] M. S-. Sakamaki and K. Amemiya, Jpn. J. Appl. Phys. 57, 120398 (2018). 